\title{
STUDENTS ERRORS ANALYSIS IN CONSTRUCTING NEGATIVE AND INTERROGATIVE SENTENCES B Y USING SIMPLE PRESENT TENSE AT THE FIRST GRADE STUDENTS OF SMP SWASTA KARTIKA 1-2 MEDAN
}

\author{
${ }^{1}$ Rahmawati, ${ }^{2}$ Ruth Debora Sari Dame Sitompul, ${ }^{3}$ Prencis Triiswati Tinambunan' \\ ${ }^{4}$ Mirahati Harefa ${ }^{5}$ Helmina Hepi Lismawati Laia \\ ${ }^{1}$ Lecturer of English Education of University of Prima Indonesia, Medan \\ ${ }^{2,3,4,5}$ Students of English Education program, University of Prima Indonesia, Medan \\ ${ }^{1}$ rahmawati@unprimdn.ac.id, ${ }^{2}$ ruthsitompul05@yahoo.co.id, \\ ${ }^{3}$ prencis.tinambunan1998@gmail.com, ${ }^{4}$ miraharefa96@gmail.com, \\ helminalaia133@gmail.com
}

Received on Nov, $21^{\text {st }}$, Revised on December, $4^{\text {th }}$, Published on December, $30^{\text {st }} 2019$

\begin{abstract}
This research was aimed to find out the kind of errors and the dominant error at the first grade students of SMP Swasta Kartika 1-2 Medan in constructing negative and interrogative sentences by using simple present tense in academic year 2019/2020. In this research, the subject was only VII-3s' class with 28 students in one class. This research was a qualitative research with a descriptive method. The data obtained from the errors made by the students in written test which consisted of 20 questions. In this study, the result of analyzed the data by calculating the errors, there were 554 case of errors with 4 types of errors made by the students in their written test of using simple present tense, they were: $197(35,55 \%)$ case of errors on misformation; 177 $(31,94 \%)$ case of errors on omission; $165(29,78 \%)$ case of errors on addition; and $15(2,70 \%)$ case of errors on misordering, where error of misformation as a type of dominant error.
\end{abstract}

Keywords: Error, Error Analysis, Simple Present Tense

\section{ABSTRAK}

Penelitian ini bertujuan untuk mengetahui jenis kesalahan dan kesalahan dominan pada siswa kelas 1 SMP Swasta Kartika 1-2 Medan dalam menyusun kalimat negatif dan interogatif dengan menggunakan simple present tense pada tahun akademik 2019/2020. Dalam penelitian ini, subjek hanya kelas VII-3 dengan 28 siswa dalam satu kelas. Penelitian ini adalah penelitian kualitatif dengan metode deskriptif. Data diperoleh dari kesalahan yang dilakukan oleh siswa dalam tes tertulis yang terdiri dari 20 pertanyaan. Dalam penelitian ini, hasil analisis data dengan menghitung kesalahan, ada 554 kasus kesalahan dengan 4 jenis kesalahan yang dibuat oleh siswa dalam tes tertulis mereka menggunakan simple present tense, yaitu: 197 (35,55\%) kasus kesalahan pada misformation; 177 (31,94\%) kasus kesalahan omission; 165 (29,78\%) kasus kesalahan pada addition; dan 15 (2,70\%) kasus kesalahan pada misordering, di mana kesalahan misformation sebagai jenis kesalahan dominan.

Kata kunci: Kesalahan, Analisis Kesalahan, Simple Present Tense 


\section{INTRODUCTION}

Writing is constructing by putting sentences in sequence, one after another. A sentence should be a self-contained unit of meaning. Meaning should flow from one sentence to the next sentences. Everyone should learn how to write to get a meaning of what they write. Scholes \& Clause (1972) argue that "writing is one way to communicate with other people besides speaking, reading, and listening".

The word "writing" seems to be very simple and easy to understand by the students because they think that writing in English and Bahasa is not far different especially when they try to arrange the sentences from affirmative to negative and interrogative of simple present tense. "The simple present is something way true in the past, is true in the present, and will be true in the future, is use for a general statement of fact" (Betty S. Azar, 2002, p. 13). However, students often make mistakes and errors especially when they try to arrange sentences in their writing process. As a real result, they write sentences ungrammatically.

The grammar of a language is the set of rules that govern its structure. Grammar determines how words are arranged to form meaningful units (Jeffrey Coghill \& Stacy Magendanz, 2003, p. 16).
In this case, students should know about the grammatical rules, especially when they write sentences and arrange sentences, they also have to know that the differences between English and Bahasa are far different, the differences in the structure of sentence may be the main reason why students often made errors in constructing a sentence. Norrish (1987) defined "Error is a systematic deviation when a learner has not learned something and consistently gets it wrong" (p. 7). To avoid the errors, Sri Rosmawati (2014) states that "the students should do more exercises in transforming affirmative simple present pattern sentences into negative and interrogative pattern sentences by paying attention in the important rules in it, especially in using verb tense in negative and interrogative sentences, the teacher should pay more attention about students' ability in using it, the teacher should deliver materials clearly and he also should pay attention to the student's activity while teaching learning process" (p. 52) and Okviyanti (2017) argues that "after found out the types of errors and the dominant errors in using simple present tense especially in completing the positive sentences and changing into negative and interrogative sentences, she suggests to avoid the same errors; English teacher should be more 
creative in teaching the students about the basic tense that is simple present tense, the students should do much practicing to form the positive sentences and then change into negative and interrogative sentences, the other researchers should be able to discuss and analyze the students' error deeply and it is also expected the other researchers to give more exercises to the students especially about forming the positive, negative, and interrogative sentences in simple present tense" (p. 46).

Based on the background above, the main objectives of this research are 1) Find out the students' errors make by the students at the first grade students of SMP Swasta Kartika 1-2 Medan in constructing negative and interrogative sentences of simple present tense, 2) Find out the dominant type of errors make by the students at the first grade students of SMP Swasta Kartika 1-2 Medan in constructing negative.

\section{METHODOLOGY}

The design in this research was a qualitative research with a descriptive analysis by doing a written test. According to Bogdan and Biklen (1982) "qualitative research is descriptive which the data is collected in the form of words or pictures rather than numbers". The instrument of this research was 20 questions in completed positive sentences, and changed it into negative sentences and interrogative sentences. Where the data of this research were some errors data which produced by the students at the first grade of SMP Kartika 1-2 Medan and the samples of this research were 28 students in VII-3s' class.

There were some procedures were conducted by the researchers to got the data collection. First, the researchers gave the written test, the tests have 20 questions where each question of the test consists of two commands; completed positive sentences with the correct verb in bracket, and changed the positive sentences into negative sentences and interrogative sentences. Second, the students were asked to complete the 20 questions by using simple present tense forms. Third, the students did the test. Fourth, the researchers collected the worksheets test of students. The last, the errors were analyzed by the researchers.

In analyzed the data, the researchers used these 4 steps to find out the data of this research in students' test, they were, a) the students' errors were identified by underlined each errors that made by the VII$3 s^{\prime}$ class or by the students, b) the students' errors were classified into 4 errors according to Dulais' Taxonomy, they were: omission, addition, misformation, and misordering, 
The percentages of errors were obtained by applied the formula below:

$$
P=\frac{F}{N} \times 100 \%
$$

$\mathrm{P}:$ The percentage of error

$\mathrm{F}$ : The number of category error

$\mathrm{N}$ : The total of number of category error

\section{RESULT AND DISCUSSION}

\section{Error of Omission}

Error of Omission is characterized with the absence of one or more items that must appear in a well-formed sentence when the students constructing a sentence like in the following table:

Table 1. Example of Omission Errors

\begin{tabular}{|c|c|c|c|c|}
\hline No & Form & Sentences & Omission of & Corrections \\
\hline 1 & $(-)$ & $\begin{array}{l}\text { I do not leave my }{ }^{\wedge} \text { at home every } \\
\text { day }\end{array}$ & $\begin{array}{l}\text { Noun } \\
\text { (cat) }\end{array}$ & $\begin{array}{l}\text { I do not leave my } \underline{c a t} \text { at home } \\
\text { every day }\end{array}$ \\
\hline 3 & (?) & $\begin{array}{l}\text { Do Bagas and Mila ^ a football } \\
\text { competition at their school? }\end{array}$ & $\begin{array}{l}\text { Verb } \\
\text { (watch) }\end{array}$ & $\begin{array}{l}\text { Do Bagas and Mila watch a } \\
\text { football competition at their } \\
\text { school? }\end{array}$ \\
\hline 5 & $(-)$ & $\begin{array}{l}\mathrm{He}^{\wedge} \text { drink a glass of milk for } \\
\text { breakfast every morning. }\end{array}$ & $\begin{array}{l}\text { Auxiliary verb }+ \\
\text { not (does }+ \text { not })\end{array}$ & $\begin{array}{l}\text { He does not drink a glass of } \\
\text { milk for breakfast every } \\
\text { morning. }\end{array}$ \\
\hline 9 & $(-)$ & $\begin{array}{l}\text { The rabbits } \wedge \text { not eat a carrot from } \\
\text { my mother. }\end{array}$ & $\begin{array}{l}\text { Auxiliary verb } \\
\text { (do) }\end{array}$ & $\begin{array}{l}\text { The rabbits } \underline{d o} \text { not eat a carrot } \\
\text { from my mother. }\end{array}$ \\
\hline 18 & (?) & $\begin{array}{l}\text { Is my mother beautiful, smart, }{ }^{\wedge} \\
\text { kind? }\end{array}$ & $\begin{array}{l}\text { Conjunction } \\
\text { (and) }\end{array}$ & $\begin{array}{l}\text { Is my mother beautiful, smart, } \\
\text { and kind? }\end{array}$ \\
\hline 20 & $(-)$ & Fried Noodle is ${ }^{\wedge}$ my favorite food. & $\begin{array}{l}\text { The word } \\
\text { (not) }\end{array}$ & $\begin{array}{l}\text { Fried Noodle is not my favorite } \\
\text { food. }\end{array}$ \\
\hline
\end{tabular}

Table 2. Example of Addition Errors

\begin{tabular}{cclll}
\hline No & Form & \multicolumn{1}{c}{ Sentences } & \multicolumn{1}{c}{ Addition of } & \multicolumn{1}{c}{ Corrections } \\
\hline $\mathbf{2}$ & $(-)$ & $\begin{array}{l}\text { She does not wash washes the } \\
\text { clothes every Sunday. }\end{array}$ & $\begin{array}{l}\text { Verb } \\
\text { (washes) }\end{array}$ & $\begin{array}{l}\text { She does not wash the clothes } \\
\text { every Sunday. }\end{array}$ \\
$\mathbf{4}$ & $(?)$ & $\begin{array}{l}\text { Does not a mouse walk behind my } \\
\text { doors? }\end{array}$ & $\begin{array}{l}\text { The word } \\
\text { (not) }\end{array}$ & $\begin{array}{l}\text { Does a mouse walk behind my } \\
\text { doors? }\end{array}$ \\
$\mathbf{6}$ & $(-)$ & $\begin{array}{l}\text { I do not studies Bahasa and English } \\
\text { every Thursday at my school }\end{array}$ & $\begin{array}{l}\text { (es-studies) } \\
\text { English every Thursday at my } \\
\text { school }\end{array}$ & $\begin{array}{l}\text { Auxiliary verb } \\
\text { Is Joe Taslim my favorite actor } \\
\text { from Indonesia? }\end{array}$ \\
\hline
\end{tabular}

The dominant type of errors were

found by the researchers that made by the students.

\section{Error of Addition.}

Error of addition is characterized with the presence of one or more items that 
appear in a well-formed sentence when the students.

\section{Error of Misformation}

Error of Misformation is characterized with the wrong morpheme or structure use in a well formed sentence when the students constructing sentence.dents constructing a sentence.

Table 3. Example of Misformation Errors

\begin{tabular}{|c|c|c|c|c|}
\hline No & Form & Sentences & Misformation of & Corrections \\
\hline 7 & $(+)$ & $\begin{array}{l}\text { The postman deliver our } \\
\text { mail every day. }\end{array}$ & $\begin{array}{l}\text { Verb on } 3^{\text {rd }} \text { singular } \\
\text { (deliver should be } \\
\text { delivers) }\end{array}$ & $\begin{array}{l}\text { The postman delivers our } \\
\text { mail every day. }\end{array}$ \\
\hline 15 & $(-)$ & $\begin{array}{l}\text { I is not a student of SMP } \\
\text { Kartika 1-2 Medan. }\end{array}$ & $\begin{array}{l}\text { Auxiliary verb } \\
\text { (is should be am) }\end{array}$ & $\begin{array}{l}\text { I } \underline{a m} \text { not a student of SMP } \\
\text { Kartika 1-2 Medan. }\end{array}$ \\
\hline 10 & $(+)$ & $\begin{array}{l}\text { She buyes some apples for } \\
\text { her grandma. }\end{array}$ & $\begin{array}{l}\text { Verb on } 3^{\text {rd }} \text { singular } \\
\text { (buyes should be buys) }\end{array}$ & $\begin{array}{l}\text { She buys some apples for her } \\
\text { grandma. }\end{array}$ \\
\hline 11. & (?) & $\begin{array}{l}\text { Are I at my uncle's house } \\
\text { every Friday? }\end{array}$ & $\begin{array}{l}\text { Verb (be) } \\
\text { (are should be am) }\end{array}$ & $\begin{array}{l}A m \text { I at my uncle's house } \\
\text { every Friday? }\end{array}$ \\
\hline 12. & $(+)$ & $\begin{array}{l}\text { My sister does a doctor in } \\
\text { the hospital. }\end{array}$ & $\begin{array}{l}\text { Verb (be) } \\
\text { (does should be is) }\end{array}$ & $\begin{array}{l}\text { My sister is a doctor in the } \\
\text { hospital. }\end{array}$ \\
\hline 14 & $(-)$ & $\begin{array}{l}\text { Our classes is big, clean, and } \\
\text { comfortable. }\end{array}$ & $\begin{array}{l}\text { Verb (be) } \\
\text { (is should be are) }\end{array}$ & $\begin{array}{l}\text { Our classes are big, clean, } \\
\text { and comfortable. }\end{array}$ \\
\hline 16 & (?) & $\begin{array}{l}\text { Mr. Jokowi does a president } \\
\text { of Indonesia? }\end{array}$ & $\begin{array}{l}\text { Verb (be) } \\
\text { (does should be is) }\end{array}$ & $\begin{array}{l}\text { Mr. Jokowi is a president of } \\
\text { Indonesia? }\end{array}$ \\
\hline 19 & $(+)$ & $\begin{array}{l}\text { Oyen are the name of my } \\
\text { cat. }\end{array}$ & $\begin{array}{l}\text { Verb (be) } \\
\text { (are should be is) }\end{array}$ & Oyen $\underline{i s}$ the name of my cat. \\
\hline
\end{tabular}

\section{Error of Misordering}

Error of Misordering is characterized with the incorrect placement of a morpheme in a well-formed sentence when the students constructing a sentence.

\section{Table 4. The Example of Misordering Errors}

\begin{tabular}{cllll}
\hline No & $\begin{array}{l}\text { For } \\
\mathbf{m}\end{array}$ & \multicolumn{1}{c}{ Sentences } & \multicolumn{1}{c}{ Misordering of } & \multicolumn{1}{c}{ Corrections } \\
\hline $\mathbf{1 3}$ & - & $\begin{array}{l}\text { Our classes not are } \\
\text { beautiful. }\end{array}$ & $\begin{array}{l}\text { Pattern negative form } \\
\text { (verb+not) }\end{array}$ & $\begin{array}{l}\text { Our classes } \text { are not } \\
\text { beautiful. }\end{array}$ \\
$\mathbf{8}$ & $?$ & $\begin{array}{l}\text { He does love his parents } \\
\text { and his brother? }\end{array}$ & $\begin{array}{l}\text { Pattern interrogative } \\
\text { (does+subject) }\end{array}$ & $\begin{array}{l}\text { Does he love his parents } \\
\text { and his brother? }\end{array}$ \\
\hline
\end{tabular}


Table 5. Recapitulation of Students' Errors

\begin{tabular}{|c|c|c|c|c|c|c|}
\hline \multirow{2}{*}{ No } & \multirow{2}{*}{ Initial } & \multicolumn{4}{|c|}{ Types of Error } & \multirow{2}{*}{ Total } \\
\hline & & $\mathrm{O}$ & A & MF & MO & \\
\hline 1 & AA & 6 & 2 & 13 & 1 & 22 \\
\hline 2 & APPH & 1 & 1 & 2 & - & 4 \\
\hline 3 & AAF & 4 & - & 5 & - & 9 \\
\hline 4 & AS & 3 & 4 & 5 & 1 & 13 \\
\hline 5 & ARR & 17 & 9 & 10 & 5 & 41 \\
\hline 6 & AS & 6 & 3 & 5 & - & 14 \\
\hline 7 & AJM & 4 & 14 & 4 & - & 22 \\
\hline 8 & $\mathrm{BF}$ & 4 & 11 & 7 & 1 & 23 \\
\hline 9 & CAR & 2 & 3 & 4 & - & 9 \\
\hline 10 & DPQ & 6 & 1 & 2 & 1 & 10 \\
\hline 11 & DA & - & 4 & - & - & 4 \\
\hline 12 & FDAP & 6 & 3 & 17 & - & 26 \\
\hline 13 & FZA & 11 & 4 & 6 & 2 & 23 \\
\hline 14 & FHAM & 3 & 4 & 6 & - & 13 \\
\hline 15 & KRL & 2 & 1 & - & - & 3 \\
\hline 16 & MAB & 2 & 12 & 11 & - & 25 \\
\hline 17 & MA & 3 & 20 & 9 & - & 32 \\
\hline 18 & MBP & 26 & 15 & 10 & - & 51 \\
\hline 19 & MHS & 5 & 1 & 13 & - & 19 \\
\hline 20 & MHP & 16 & 13 & 12 & - & 41 \\
\hline 21 & MIPA & 31 & 9 & 14 & 1 & 55 \\
\hline 22 & MRZ & 2 & 1 & 16 & 3 & 22 \\
\hline 23 & MH & - & 4 & 1 & - & 5 \\
\hline 24 & MBS & 3 & 10 & 5 & - & 18 \\
\hline 25. & RSS & 3 & 1 & 7 & - & 11 \\
\hline 26. & SDP & 2 & 10 & 5 & - & 17 \\
\hline 27. & THK & 3 & 1 & 5 & - & 9 \\
\hline 28. & ZS & 6 & 4 & 3 & - & 13 \\
\hline \multicolumn{2}{|c|}{ Total Errors } & 177 & 165 & 197 & 15 & 554 \\
\hline
\end{tabular}

From the table above, the calculations for the percentages of errors made by the students in constructing negative and interrogative sentences were 554 cases which were divided into four calculations, they were:

a. $\mathrm{POM}=\frac{\text { Total Omission }}{\text { Total Bmons }} \times 100 \%=\frac{177}{554} \times 100 \%=31,94 \%$

$$
\mathrm{PAD}=\frac{\text { Total Addition }}{\text { Total Brrons }} \times 100 \%=\frac{165}{554} \times 100 \%=29,70 \%
$$

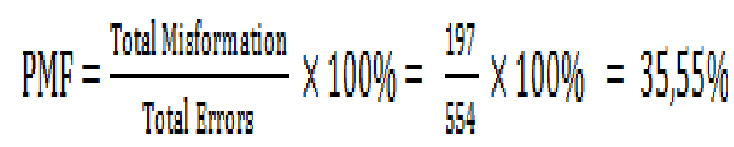

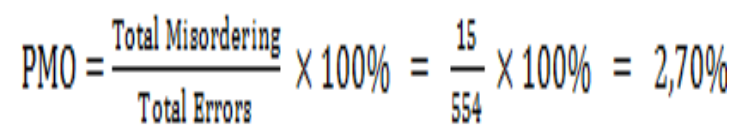

The result of the data analysis above showed that: First, the total numbers of errors made by the students at the first grade students of SMP Swasta Kartika 1-2 Medan in constructing negative and interrogative sentences of simple present tense were 554 cases of errors. They were divided into four types namely: 177 $(31,94 \%)$ errors of omission, 165 (29,78\%) errors of addition, 197 (35,55\%) errors of misformation and $15(2,70 \%)$ errors of misordering. And the dominant type of errors made by the students at the first grade students of SMP Swasta Kartika 1-2 Medan in constructing negative and interrogative sentences of simple present tense was error of misformation with 197 $(35,55 \%)$ cases of errors. 


\section{CONCLUSION}

Based on the results of the data analysis, it was concluded as the following:

1) The students of the first grade at SMP Kartika 1-2 Medan got low understanding in using simple present tense in constructing negative and interrogative sentences, because they were commonly made errors in their written test were namely: omission, addition, misformation, and misordering.

2) Error of misformation was type of dominant errors made by the students of SMP Kartika 1-2 Medan in using simple present tense with 197 cases of errors $(35,55 \%)$, and while in omission 177 (31,94\%), addition $165(29,78 \%)$, and misordering $15(2,70 \%)$ cases of errors.

\section{SUGGESTION}

In constructing words students should know about the grammatical rules, especially when they wrote sentences and arrange sentences, they also have to know that the differences between English Bahasa are far different; the differences in structure of sentence maybe the main reason why students often made errors in constructing a sentence. To avoid the errors, there are some suggestions the researchers would like to give as the following, 1) English teacher should be more active and creative to explaining, deliver materials clearly, and teaching the students with unique ways about the basic tense of simple present tense where it is hoped that English teacher can minimize the students' errors in the future, 2) The students should do much

practicing about how the ways to construct positive sentences to negative and interrogative sentences with follow the patterns of simple present tense, and 3) The other researchers should be able to analyze the students' errors more deeply and give more exercises to the students in constructing negative and interrogative sentences by using simple present tense.

\section{REFERENCES}

Azar, B.S. (1989). Understanding and

Using English Grammar (third ed.). New Jersey:Prentice Hall, p.13. Available from: https://archive.org/details/BettyAzar.Un derstandingAndUsingEnglishGrammar/ page/n13

Brown, H.D. (1980). Principles of

Language Learning and Teaching. NewJersey:Prentice-Hall, Inc., College Operations Department, Englewood Cliffs.

Coghill, Jeffrey and Stacy Magendanz. (2003). English Grammar. NewYork: Wiley Publishing, Inc. Equivalence. New York:Univ. Press. 
Cook, S. J., and Richard W.S. (1980). The

Scope of Grammar: The Study of Modern Grammar. New York: McGraw Hill Book Company.

Dulay, Heidi, Marina Burt, and Stephen Krashen. (1982). Language Two. New

York:Oxford University Press.

Harmer, Jeremy. (2007). The Practice of English Language Teaching. USA:

Pearson Education Limited.

Lampung, University. (2005). Pedoman

Penulisan Karya Ilmiah Universitas

Lampung. Bandar Lampung: Unila

Press.

Muhsin, M.A. (2016). Analysing TheStudents Errors In Using Simple Present (A Case Study at Junior High School in Makassar). Makassar: Journal. Universitas Muhammadiyah Makassar, Indonesia.

Ndruru, E. (2016). Error Analysis On The Student's Use Of Simple Present Tense In Essay Writing At SMA Mardi Lestari Medan. Medan: Thesis. Universitas Prima Indonesia.

Norhayati M. Wahi. (2002). A Study of Error Analysis of The Most Common Grammatical Error in Constructing Sentences by Form for Malay Students at A Selected School in Klang. Malaysia: Thesis. Universiti Pendidikan
Sultan Idris.

Okviyanti. (2017). Students' Error in Using Simple Present Tense at The First Grade of SMP Kartika 1-2 Medan. Medan: Thesis. Universitas Prima Indonesia.

Pardede, A.S.M. (2017). An Analysis of Students' Error in Constructing Negative and Interrogative Sentence by Using Simple Past Tense. Medan: Journal. Universitas Prima Indonesia.

Pardede, A.S.M. (2017). An Analysis of Students' Error in Constructing Negative and Interrogative Sentence by Using Simple Past Tense. Medan: Journal. Universitas Prima Indonesia.

Pardiyono. (2000). Teaching Genre-Based Writing. Practical Shots for Effective Classroom Activities on Genre-Based Writing. Surakarta: UMS Press.

Scholes, R., Clause, C.H., (1972). Elements of Writing. Oxford University Press, NewYork.

Wati, Rahmawati. (2019). The Effect of Using Role Playing Strategy on Students' Achievement in Speaking English at SMP Muhammadiyah 01 Medan. ISSN: $2527-8835$

Wishon, George E. and Julia M. B. (1980). Let's Write English. (revised ed.). New York: Litton Educational Publishing. 